\title{
Application of Antimicrobial Peptides for Disease Control in Plants
}

\author{
Yu-Jin Jung ${ }^{1,2}$, Kwon-Kyoo Kang ${ }^{1,2 *}$ \\ ${ }^{1}$ Department of Horticulture, Hankyong National University, Anseong 456-749, Korea \\ ${ }^{2}$ Institute of Genetic Engineering, Hankyong National University, Ansung, 456-749, Korea
}

\begin{abstract}
A large number of antimicrobial peptides (AMPs) from different organisms have been characterized to date. AMPs are small molecular weight proteins with broad spectrum antimicrobial activity against bacteria, viruses, and fungi. Several diseases in plants could result in serious losses and decreasing quality and safety of agricultural products. Being an agent for plant defense, AMPs kill target cells through diverse mechanisms once in a target microbial membrane. Cathelicidins, defensins and thionins are the three major groups of epidermal AMPs in human and plants. Plant AMPs are structurally and functionally diverse and can be directed against other organisms, like herbivorous insects. The biological activity of plant AMPs primarily depends on interactions with membrane lipids. Several antimicrobial peptides have been expressed in transgenic plants to confer disease protection. Antimicrobial peptides are interesting compounds that can be efficiently exploited for disease control in plants in a way that complies with the strict regulations on the efficacy and safety of disease control strategy.
\end{abstract}

Keywords Antimicrobial peptide, Cathelicidins, Defensins, Thionins, Plant protection

\section{INTRODUCTION}

Plant diseases caused by viruses, bacteria and fungi affect crops, and have an effect on significant losses or decrease the quality and safety of agricultural products (Agrios 2005). In order to reduce yield loss, development of novel breeding strategies is urgently needed. Plants have long been known to exhibit mechanisms that enabled them to detect and defend against microbial attack. In response to microbial attack, plants have activated a complex series of responses that lead to the local and systemic induction of a broad-spectrum of antimicrobial defenses (Montesinos 2007).

In human medicine, antimicrobial peptides (AMPs) have been considered as potential therapeutic sources of future antibiotics because of their broad-spectrum activities and different mechanisms of action compared to conventional antibiotics. Although AMPs possess considerable benefits as new generation antibiotics, their clinical and commercial development still have some limitations, such as potential toxicity, susceptibility to proteases, and high cost of peptide production. In order to overcome those obstacles, extensive efforts have been carried out.

Antimicrobial peptides (AMPs) are endogenous polypeptides produced by multicellular organisms in order to protect a host from pathogenic microbes. AMPs are also defined as host defense peptides because of their essential role in constituting the innate immunity system (Zasloff 2002; Nguyen et al. 2011). AMPs are short sequence peptides with generally fewer than 50 amino acid residues, most of which have antimicrobial activity against a broad spectrum of pathogens. In general, when AMPs are folded in membrane mimetic environments, one side of AMPs is positively charged (mainly due to lysine and arginine residues) and the other side contains a considerable proportion of hydrophobic residues (Zasloff 2002; Hancock et al. 1997; Hancock and Lehrer 1998). The cationic properties of AMPs are implicated in their selective interaction with the negatively charged surfaces of microbial membranes,

Received March 26, 2014; Revised March 28, 2014; Accepted March 29, 2014; Published March 31, 2014

*Comesponding author Kwon-Kyoo Kang, kykang@hknu.ac.kr, Tel: +82-31-670-5104, Fax: +82-31-670-5109 
resulting in the accumulation of AMPs on the membrane surface. And their hydrophobic portions are responsible for the interaction with hydrophobic components of the membrane. From this complex interaction with the membrane, major rearrangements of its structure occur, which may result from the formation of peptide-lipid specific interactions, the peptide translocation across the membrane and interaction with intracellular targets or the most common mechanism, a membranolytic effect (Nguyen et al. 2011; Hancock 1997).

AMPs show broad-spectrum antimicrobial activities against various microorganisms, including Gram-positive and Gram-negative bacteria, fungi, and viruses (Zasloff 2002). Most AMPs, with their amphipathic nature, directly act on the membrane of the pathogen. They are a first line of defense in plants and animals, and resistance against them is much less observed compared with current antibiotics (Hancock 1997). AMPs from various sources have been demonstrated to confer resistance against fungal and bacterial pathogens in an array of genetically engineered plant species, including Arabidopsis (Maloy 1995), tobacco (Ramamoorthy et al. 2006; Kang et al. 2009; Park et al. 2002), Chinese cabbage (Jung et al. 2012), rice (Gordon et al. 2005; Oyston et al. 2009), tomato (Lupetti et al. 2000), cotton (Lupetti et al. 2003), potato (Brouwer et al. 2011), pear (Hwang et al. 1998), banana (Ramamoorthy et al. 2006) and hybrid poplar (Nguyen et al. 2005).

In this review, we describe the potentials of AMPs as novel disease control agent in plants, and its structural functions that relate to the mechanism of its inhibitory action to invading pathogen.

\section{History and structural information of antimicrobial peptides}

Antimicrobial peptides (AMPs) are oligopeptides with a varying number (from five to over a hundred) of amino acids. The discovery of AMPs dates back to 1939, when Dubos (Dubos 1939) extracted an antimicrobial agent from a soil Bacillus strain. This extract was demonstrated to protect mice from pneumococci infection. In the following year, Hotchkiss and Dubos (Hotchkiss and Dubos 1940) fractionated this extract and identified an AMP which was named gramicidin. Despite some reported toxicity associated with intraperitoneal application (Hotchkiss and Dubos 1940), gramicidin was found effective for topical treatment of wounds and ulcers (Van Epps 2006). In 1941, another AMP, tyrocidine, was discovered and found to be effective against both Gram-negative and Gram-positive bacteria (Dubos and Hotchkiss 1941). However, tyrocidine exhibited toxicity to human blood cells (Rammelkamp 1942). In the same year, another AMP was isolated from a plant Triticumaestivum (Balls 1942), which was later named purothionin and found effective against fungi and some pathogenic bacteria (Ohtani et al. 1977). The first reported animal-derived AMP is defensin, which was isolated from rabbit leukocytes in 1956 (Hirsch 1956). In the following years, bombinin from epithelia and lactoferrin from cow milk were both described (Groves et al. 1965). During the same time, it was also proven that human leukocytes contain AMPs in their lysosomes (Zeya and Spitznagel 1963). In total, more than 5,000 AMPs have been discovered or synthesized up to date (Zhao et al. 2013). Natural AMPs can be found in both prokaryotes (e.g., bacteria) and eukaryotes (e.g., protozoan, fungi, plants, insects, and animals) (Conlon and Sonnevend 2010). Most AMPs are produced by specific cells at all times, while the production of some AMPs is inducible.

AMPs can be classified into four groups based on their structures: $\alpha$-helical peptides, $\beta$-sheet peptides which contain two or more disulfide bonds, $\beta$-hairpin or loop which possess single disulfide bond and/or cyclization of the peptide chain, and extended peptides (Zasloff 2002; Nguyen et al. 2011; Hancock and Lehrer 1998). Among these structural groups, $\alpha$-helix and $\beta$-sheet structures are more common and $\alpha$-helical peptides are the most studied AMPs to date (Arnold 1977) (Table 1). The a-helical AMPs, including magainin, cecropin, and pexiganan, constitute a representative class of AMPs that are the most well established in structure-activity relationships. This group of peptides is usually unstructured in aqueous solution and forms amphipathic helices in membranes or membrane-mimicking environments (Seo et al. 2012). Most a-helical AMPs disrupt bacterial membranes, and several mechanisms of action employed by various AMPs have been proposed. The a-helical amphipathic peptides form barrel-like bundles in the bacterial membranes, and 
these transmembrane clusters line amphipathic pores (barrel-stave model). Many a-helical AMPs, including some magainins and cecropins, can disrupt bacterial membranes by forming carpet-like clusters of peptides. The peptides adsorb and align in parallel to the surface of bacterial membranes, then the membranes are collapsed into micelle-like structures by high concentrations of peptides (Fig. 1). The a-helical AMPs, such as some magainins and protegrins, form toroidal pores to disrupt the bacterial membranes (toroidal pore model) (Zasloff 2002; Nguyen et al. 2011; Hancock and Lehrer 1998). The $\beta$ -sheet AMPs, such as $\alpha$-, $\beta$-defensins, and protegrin, are stabilized by disulfide bridges, and form relatively rigid structures. Many of $\beta$-sheet AMPs exert their antimicrobial

Table 1. Representative antimicrobial peptides.

\begin{tabular}{|c|c|c|c|c|c|c|}
\hline Type & AMPs & Size & Characteristic & Origin & Activity & Reference \\
\hline \multirow{5}{*}{$\begin{array}{l}\text { a-helical peptides } \\
\text { of Lack in cysteine }\end{array}$} & Magainin & $\begin{array}{l}\sim 2.5 \mathrm{kDa} \\
23 \text { amio } \\
\text { acid }(\mathrm{aa})\end{array}$ & Lys rich & $\begin{array}{l}\text { analog of } \\
\text { frogs }\end{array}$ & $\begin{array}{c}\text { Gram } \\
\text { positive/negative } \\
\text { bacteria, fungi, } \\
\text { parasite }\end{array}$ & $\begin{array}{c}\text { Gesell et al. } \\
1997\end{array}$ \\
\hline & Cecropins & $\begin{array}{l}\sim 4 \mathrm{kDa} \\
30 \sim 45 \text { aa }\end{array}$ & $\begin{array}{c}\text { Lys rich, } \\
\text { Amidation of } \\
\text { C-terminal }\end{array}$ & $\begin{array}{l}\text { Blood of } \\
\text { insects }\end{array}$ & $\begin{array}{c}\text { Gram } \\
\text { positive/negative } \\
\text { bacteria }\end{array}$ & $\begin{array}{c}\text { Holak et al. } \\
1988\end{array}$ \\
\hline & Cepropin P1 & $\begin{array}{l}\sim 4 \mathrm{kDa}, \\
30 \sim 45 \text { aa }\end{array}$ & $\begin{array}{l}\text { Amidation of } \\
\text { C-terminal }\end{array}$ & $\begin{array}{l}\text { paneth cell } \\
\text { from small } \\
\text { intestine of } \\
\text { pigs }\end{array}$ & $\begin{array}{c}\text { Gram negative } \\
\text { bacteria }\end{array}$ & $\begin{array}{c}\text { Sipos et al. } \\
1992\end{array}$ \\
\hline & Buforin & 39 aа & $\begin{array}{l}\text { Similarity to } \\
\text { C-terminal of } \\
\text { Histone IIa }\end{array}$ & $\begin{array}{l}\text { Stomach of } \\
\text { American Bull } \\
\text { Frog }\end{array}$ & $\begin{array}{c}\text { Gram } \\
\text { positive/negative } \\
\text { bacteria, fungi, }\end{array}$ & $\begin{array}{c}\text { Yi et al. } \\
1996\end{array}$ \\
\hline & $\begin{array}{l}\text { hCAP18/ } \\
\text { LL-37 }\end{array}$ & $\begin{array}{l}18 \mathrm{kDa} \\
37 \mathrm{aa}\end{array}$ & Helical C-terminal & humans & $\begin{array}{c}\text { Gram } \\
\text { positive/negative } \\
\text { bacteria, fungi, }\end{array}$ & $\begin{array}{l}\text { Gudmundsson } \\
\text { et al. } 1996\end{array}$ \\
\hline \multirow{3}{*}{$\begin{array}{l}\text { Cationic peptide } \\
\text { enriched for } \\
\text { specific amino } \\
\text { acid }\end{array}$} & Bac5, Bac7 & 43 or 59 aa & \multirow{3}{*}{$\begin{array}{l}\text { Lack in cysteine } \\
\text { residue, } \\
\text { rich in proline, } \\
\text { arginine, } \\
\text { phenylalanine, } \\
\text { glycine, tryptophan }\end{array}$} & $\begin{array}{l}\text { Neutrophils } \\
\text { of cattle }\end{array}$ & \multirow{3}{*}{$\begin{array}{c}\text { Gram } \\
\text { positive/negative } \\
\text { bacteria }\end{array}$} & $\begin{array}{c}\text { Scocchi et al. } \\
1994\end{array}$ \\
\hline & PR39 & 39 aа & & $\begin{array}{c}\text { small intestine } \\
\text { of pigs }\end{array}$ & & $\begin{array}{c}\text { Agerberth et al. } \\
1991\end{array}$ \\
\hline & Indolicidin & 13 aа & & $\begin{array}{c}\text { Neutrophils } \\
\text { of cattle }\end{array}$ & & $\begin{array}{c}\text { Selsted et al. } \\
1992\end{array}$ \\
\hline \multirow{3}{*}{$\begin{array}{l}\text { B-hairpin or loop } \\
\text { due to the } \\
\text { presence of a } \\
\text { single disulfide } \\
\text { bond }\end{array}$} & Dodecapeptide & 12 aa & \multirow{3}{*}{$\begin{array}{c}\text { and/or cyclization } \\
\text { of the peptide } \\
\text { chain }\end{array}$} & $\begin{array}{l}\text { Neutrophils } \\
\text { of cattle }\end{array}$ & \multirow{3}{*}{$\begin{array}{c}\text { Gram } \\
\text { positive/negative } \\
\text { bacteria }\end{array}$} & $\begin{array}{c}\text { Romeo et al. } \\
1988\end{array}$ \\
\hline & Brevinins & $20 ` 34$ aa & & amphibians & & $\begin{array}{c}\text { Conlon et al. } \\
1999\end{array}$ \\
\hline & Raqnalexin & 20 aa & & amphibians & & $\begin{array}{c}\text { Clark et al. } \\
1994\end{array}$ \\
\hline \multirow{3}{*}{$\begin{array}{l}\beta \text {-sheet peptides } \\
\text { due to the } \\
\text { presence of } 2 \text { or } \\
\text { more disulfide } \\
\text { bonds }\end{array}$} & Defensins & $\begin{array}{l}\sim 4 \mathrm{kDa}, \\
29 \sim 45 \text { aa }\end{array}$ & \multirow{2}{*}{$\begin{array}{l}\text { Arg-rich, salt or } \\
\text { iron sensitive } \\
\text { activity }\end{array}$} & $\begin{array}{l}\text { Neutrophils } \\
\text { of rabbits } \\
\text { and humans }\end{array}$ & \multirow{3}{*}{$\begin{array}{c}\text { Gram } \\
\text { positive/negative } \\
\text { bacteria, fungi, } \\
\text { cytotoxicity }\end{array}$} & $\begin{array}{c}\text { Pardi et al. } \\
1992\end{array}$ \\
\hline & $\beta$-Defensin & $38 \sim 42$ aa & & $\begin{array}{c}\text { Bovine } \\
\text { leukocytes }\end{array}$ & & $\begin{array}{l}\text { Zimmermann } \\
\text { et al. } 1995 \\
\end{array}$ \\
\hline & Protegrin & $16 \sim 18$ aa & S-S bond & $\begin{array}{c}\text { Porcine } \\
\text { leukocytes }\end{array}$ & & $\begin{array}{c}\text { Fahrner et al. } \\
1996\end{array}$ \\
\hline
\end{tabular}


activities by disrupting bacterial membranes. They are perpendicularly inserted or tilted into the lipid bilayer to form toroidal pores, and hydrophilic regions of the peptides are associated with the polar head groups of the membranes (Nguyen et al. 2011). While most AMPs belong to one of the four classes, some AMPs do not belong to any of these groups. Some of which contain two different structural components (Brouwer et al. 2011). Also, many peptides form their active structure only when they interact with the membranes of target cells.

These AMP gene families have little in common other than their ability to kill microbes. Also, this structure appears critical to their ability to interact with the negatively charged microbial membrane in the initiation of antimicrobial effects.

\section{The major groups of AMPs: Cathelicidins, Defensins and Thionins}

Like AMPs of animal origin, the molecular diversity of AMPs from plants is striking (Padovan et al. 2010). The most common classes are thionins, defensins, and lipid transfer proteins. Plant AMPs share the following important features: They are small cationic peptides with molecular masses of 2-10 kDa. The structures of these small peptides are stabilized through formation of 2-6 disulfide bridges. The activities of plant AMPs are primarily directed against fungal, oomycete, and bacterial microorganisms, but certain members of a class can be directed against other targets, including herbivorous insects. Different classes of plant AMPs are as follows.

Cathelicidins form a distinct class of proteins present in the innate immunity of mammals (Zanetti 2004). Similar to

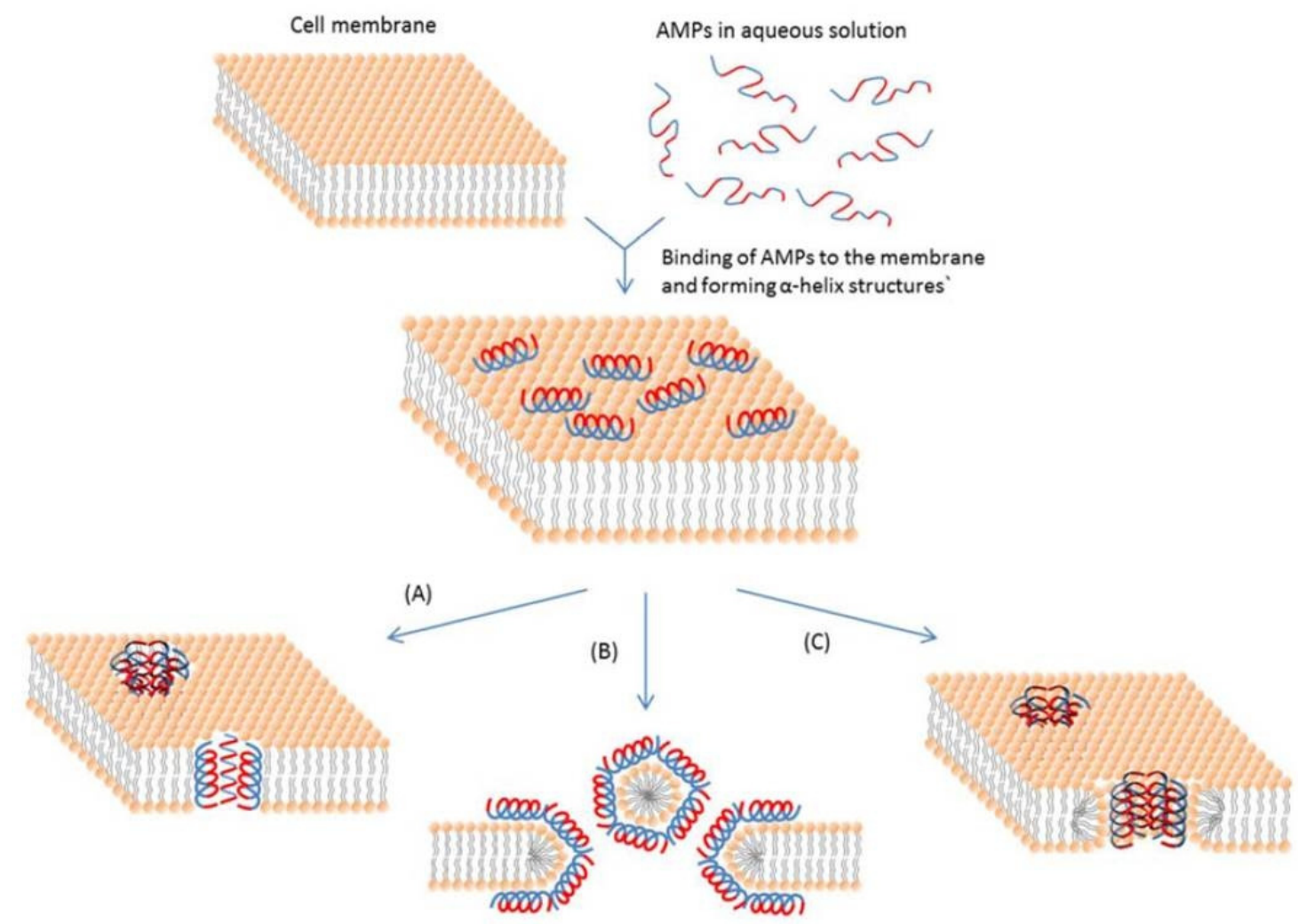

Fig. 1. Schematic representation of some action mechanisms of membrane-active AMPs.

(A) Barrel-Stave model. AMP molecules insert themselves into the membrane perpendicularly. (B) Carpet model. Small areas of the membrane are coated with AMP molecules with hydrophobic sides facing inward leaving pores behind in the membrane. (C) Toroidal pore model. This model resembles the Barrel-stave model, but AMPs are always in contact with phospholipid head groups of the membrane. The blue color represents the hydrophobic portions of AMPs, while the red color represents the hydrophilic parts of the AMPs. (Bahar and Ren 2013). 
defensins, they act as precursor molecules that can release an antimicrobial peptide after proteolytic cleavage. But their structural features clearly distinguish them from defensins. The discovery of cathelicidins commenced after the isolation of the antimicrobial peptide Bac5 from bovine neutrophils, and the realization that they are cleaved from inactive precursors (Zanetti et al. 1990; Frank et al. 1990). In humans, the cathelicidin family is limited to a single gene, CAMP, with the protein product most frequently referred to as hCAP18/LL-37 (Cowland et al. 1995). The expression of hCAP18/LL-37 was initially detected directly in human skin keratinocytes only at sites of inflammation, although more recently it has also been found to be constitutively produced in specialized keratinocytes such as those of the nail or in neonatal skin and in eccrine glands (Dorschner et al. 2004). The first mature peptide isolated from this gene product was referred to as LL-37 because it begins with two leucine residues and is 37 amino acids long. This peptide forms a linear amphipathic a-helix. The primary structure of LL-37, LLGDF-FRKSK-EKIGKEFKRI-VQRIK-DFLRN-LVPRT-ES, was given along with other a-helical cathelicidin-derived antimicrobial peptides. The cathelicidin proteins are characterized by a highly conserved $\mathrm{N}$-terminal domain of about 100 amino acid residues. This $14 \mathrm{kDa}$ cathelin-like domain is flanked by a signal peptide domain (approximately 30 residues long) on its $\mathrm{N}$-terminus, and by an antimicrobial peptide region on its $\mathrm{C}$-terminus. This signal peptide is cleaved off once it has fulfilled its purpose of targeting the cathelicidin to storage granules or to the exterior of the cell. The formation of two disulfide-bridges finalizes post-transcriptional processing. Cathelicidin proteins have been extensively studied in mammals to date. However, cathelicidins were also recently found in chicken and three species of fish (Zanetti et al. 1991).

Defensins were first isolated from seeds of monocot and dicot species (Terras et al. 1995). Typical plant defensins form two additional disulfide bonds. Plant and arthropod defensins consist of a $\beta a \beta \beta$ pattern, whereas mammalian $\beta$-defensins contain an $N$-terminal $\alpha$-helix and an overall $\alpha$ $\beta \beta \beta$-fold. Plant defensins are small 45-54 amino acids long cationic peptides. Defensins are widely distributed among dicots and monocots. The genome of A. thaliana alone was shown to encode more than 300 defensin-like (DEFL) peptides, $78 \%$ of which have a $\mathrm{CSa} \beta$ motif (Silverstein et al. 2005). Unlike animal defensins, few plant defensins are active against bacteria (Franco et al. 2006). Instead, the most common activity of these peptides is directed against diverse fungi (Osborn et al. 1995). Besides these antimicrobial activities, specific defensins have been reported to inhibit protein synthesis (Mendez et al. 1990). Plant defensins also influence plant growth and development. Altered expression of the tomato defensin DEF2 in transgenic tomato plants reduced pollen viability and seed production (Stotz et al. 2009). Constitutive expression of this defensin had pleiotropic effects on plant development. In contrast to the above examples, the following developmental process has been studied at the mechanistic level: S-locus Cys-rich (SCR) protein as DEFL peptide for interaction with SPK, S-locus receptor kinase (SRK) to trigger self-incompatibility, a response that prevents self-fertilization via inhibition of pollen tube growth and that favors outcrossing (Nasrallah 2002). Also, L3 loop connecting $\beta 2$ and $\beta 3$ and the $a$ -helical region are important for recognition of SCR by SRK (Sato et al. 2004). PR-13 is closely related to the defensing peptide $\mathrm{NaD} 1$ and more distantly related to thionins. Silencing of the tobacco defensin PR-13 resulted in increased susceptibility of Nicotiana attenuata to Pseudomonas syringae pv. tomato DC3000 under glasshouse conditions and increased susceptibility to opportunistic Pseudomonas spp. and mortality in the native habitat (Rayapuram et al. 2008). Based on these data, defensins are clearly important for plant defense, and their evolutionary diversification is the basis for various ecological functions. Defensins were originally grouped with the thionins and defined as g-thionins. However, structural comparisons to insect defensins required a reclassification of this group of AMPs as defensins (Bruix et al. 1993).

The first AMP isolated from plants was a thionin from the endosperm of wheat. Thionins have homologues from various taxa, such as viscotoxins, phoratoxins, and crambins (Mendez et al. 1990; Bruix et al. 1993). Thionins have four disulfide bonds from cereals and Pyrularia pubera, while other dicotyledonous thionins have three disulfide bonds. Thionins from the endosperm and leaf of barley inhibit the fungi Drechslera teres, a pathogen of barley, and Thielaviopsis 
paradoxa, a pathogen of sugar cane (Bohlmann et al. 1988). Thionins also affect organisms other than plant pathogens. Purothionins are toxic to small mammals when injected intravenously or intraperitoneally but not when administered orally (Rayapuram et al. 2008). The mature thionin peptides are generally $45-47$ amino acids in length and derived from preproproteins that contain an N-terminal signal peptide for targeting to the endoplasmic reticulum (ER) and a C-terminal acidic peptide that is thought to neutralize the activity of the cationic thionin. Also, thionins are targeted to the vacuole to the action of basic chitinase and $\beta$-1,3-glucanase (Romero et al. 1997).

\section{Transgenic plants expressing antimicrobial peptides}

Antimicrobial peptides (AMPs) have been the object of attention in past years as candidates for plant protection products. Thus, gene constructions including sequences coding for AMPs have been expressed on model or crop plants providing different degrees of protection against plant pathogens. Transgenic plants introduced with defensin

Table 2. Summary of genetic engineering for antimicrobial peptides (AMPs) from plants.

\begin{tabular}{|c|c|c|c|c|c|}
\hline $\begin{array}{l}\text { AMP/ Signal } \\
\text { sequence }\end{array}$ & $\begin{array}{l}\text { Source for } \\
\text { defensin }\end{array}$ & Transgenic plant & Promoter & Pathogens/pests tested* & Reference \\
\hline BrD1 & Brassica rapa & Rice & $\begin{array}{c}\text { Rice } \\
\text { cytochrome C }\end{array}$ & $\begin{array}{l}\text { Nilaparvata lugens } \\
\text { (brown planthopper insect) }\end{array}$ & Choi et al. 2009 \\
\hline RsAFP2 & Radish & Wheat/rice & $\begin{array}{c}\text { Maize } \\
\text { ubiquitin/ } \\
\text { CaMV 35S }\end{array}$ & $\begin{array}{c}\text { Fusarium graminearum, } \\
\text { Rhizoctonia cerealis, } \\
\text { Magnaporthe oryzae, } \\
\text { Rhizoctonia solani, } \\
\text { Alternaria longipes }\end{array}$ & $\begin{array}{c}\text { Li et al. } 2011 \\
\text { Jha and Chattoo } 2010 \\
\text { Terras et al. } 1995\end{array}$ \\
\hline Dm-AMP1 & Dahlia merckii & Rice/papaya & $\begin{array}{l}\text { Maize } \\
\text { ubiquitin/ } \\
\text { D35S }\end{array}$ & $\begin{array}{c}\text { Magnaporthe oryzae, } \\
\text { Rhizoctonia solani, } \\
\text { Phytophthora palmivora }\end{array}$ & $\begin{array}{l}\text { Jha et al. } 2009 \\
\text { Zhu et al. } 2007\end{array}$ \\
\hline MsDef1 & Alfalfa & Tomato & CaMV 35S & Fusarium oxysporum & Abdallah et al. 2010 \\
\hline NmDef02 & $\begin{array}{l}\text { Nicotiana } \\
\text { megalosiphon }\end{array}$ & Tobacco/potato & CaMV 35S & $\begin{array}{c}\text { Phytophthora parasitica, } \\
\text { Peronospora hyoscyami, } \\
\text { Phytophthora infestans, } \\
\text { Alternaria solani }\end{array}$ & Portieles et al. 2010 \\
\hline WjAMP-1 & Wasabi & Melon & CaMV $35 \mathrm{~S}$ & $\begin{array}{c}\text { Fusarium oxysporum, } \\
\text { Alternaria solani }\end{array}$ & Ntui et al. 2010 \\
\hline cdef1 & Chili & Tomato & CaMV 35S & $\begin{array}{c}\text { Fusarium sp., } \\
\text { Phytophthora infestans }\end{array}$ & Zainal et al. 2009 \\
\hline $\mathrm{BjD}$ & Mustard & Peanut & CaMV 35S & $\begin{array}{l}\text { Phaeoisariopsis personata, } \\
\text { Cercospora arachidicola, }\end{array}$ & $\begin{array}{l}\text { Swathi Anuradha et al. } \\
2008\end{array}$ \\
\hline alfAFP & Alfalfa & Potato & FMV35S & Verticillium dahliae & Gao et al. 2000 \\
\hline DRR206 & Pea & Canola & CaMV 35S & $\begin{array}{c}\text { slight increase in resistance } \\
\text { to Leptosphaeria maculans }\end{array}$ & Wang et al. 1999 \\
\hline $\begin{array}{c}\text { wasabi } \\
\text { defensin }\end{array}$ & Wasabi & Rice & Ubiquitin-1 & Magnaporthe grisea & Kanzaki et al. 2002 \\
\hline MiAMP1 & $\begin{array}{l}\text { Macadamia } \\
\text { integrifolia }\end{array}$ & Canola & $\mathrm{E} 12 \Omega$ & Leptosphaeria maculans & Kazan et al. 2002 \\
\hline
\end{tabular}

Note: CaMV = Cauliflower Mosaic Virus, E12 $\Omega$ = the 5 ' enhancer sequence from CaMV35S promoter + omega sequence from TMV, D35S = double CaMV35S + omega sequence from TMV, FMV = Figwort Mosaic Virus, ND = Not Determined, $\mathrm{TSP}=$ total soluble protein, ${ }^{*}$ the transgenic plant displayed increased resistance to the tested organisms unless otherwise specified. 
Table 3. Summary of genetic engineering for antimicrobial peptides (AMPs) from animals.

\begin{tabular}{|c|c|c|c|c|c|c|}
\hline AMP & $\begin{array}{l}\text { Source for } \\
\text { AMP }\end{array}$ & $\begin{array}{c}\text { Transgenic } \\
\text { plant }\end{array}$ & $\begin{array}{c}\text { Signal } \\
\text { sequence }\end{array}$ & Promoter & $\begin{array}{l}\text { Pathogens/ } \\
\text { pests tested* }\end{array}$ & Reference \\
\hline Tachyplesin I & $\begin{array}{l}\text { Horseshoe } \\
\text { crabs }\end{array}$ & Potato & $\begin{array}{c}\text { Barley } \\
\text { a-hordothionin }\end{array}$ & CaMV 35S & $\begin{array}{l}\text { Slight increase in resistance to } \\
\text { Erwinia spp. }\end{array}$ & $\begin{array}{c}\text { Allefs et al. } \\
1996\end{array}$ \\
\hline Cecropin A & $\begin{array}{l}\text { Giant silk } \\
\text { moth }\end{array}$ & Tobacco & Cecropin B & CaMV 35S & $\begin{array}{l}\text { No significant increase in } \\
\text { resistance to } \\
\text { Pseudomonas syringae pv. } \\
\text { tabaci }\end{array}$ & $\begin{array}{l}\text { Hightower } \\
\text { et al. } 1994\end{array}$ \\
\hline MB39 & Synthetic & Tobacco & $\begin{array}{c}\text { Barley } \\
\text { a-amylase }\end{array}$ & PiII & $\begin{array}{c}\text { Pseudomonas syringae pv. } \\
\text { tabaci }\end{array}$ & $\begin{array}{c}\text { Huang et al. } \\
1997\end{array}$ \\
\hline Cecropin B & $\begin{array}{l}\text { Giant silk } \\
\text { moth }\end{array}$ & $\begin{array}{l}\text { Tobacco/ } \\
\text { Rice }\end{array}$ & $\begin{array}{l}\text { Barley leaf } \\
\text { thionin/ rice } \\
\text { chitinase }\end{array}$ & $\begin{array}{l}\text { CaMV 35S/ } \\
\text { E7 } \Omega \text { In }\end{array}$ & $\begin{array}{l}\text { No significant increase in } \\
\text { resistance to } \\
\text { Pseudomonas syringae and } \\
\text { Pseudomonas solanacearum/ } \\
\text { Xanthomonas oryzae pv. } \\
\text { oryzae }\end{array}$ & $\begin{array}{l}\text { Florack et al. } \\
1995 / \\
\text { Sharma et al. } \\
2000\end{array}$ \\
\hline Sarcotoxin IA & Flesh fly & Tobacco & $\begin{array}{l}\text { Tobacco PR } \\
\text { protein }\end{array}$ & $\mathrm{E} 12 \Omega$ & $\begin{array}{l}\text { Pseudomonas syringae pv. } \\
\text { tabaci and Erwinia carotovora }\end{array}$ & $\begin{array}{c}\text { Ohshima et al. } \\
1999\end{array}$ \\
\hline Attacin E & $\begin{array}{l}\text { Giant silk } \\
\text { moth }\end{array}$ & Pear & Attacin E & $2 \times$ CaMV35S & Erwinia amylovora & $\begin{array}{c}\text { Reynoird et al. } \\
1999\end{array}$ \\
\hline D4E1 & Synthetic & Tobacco & not specified & D35S & $\begin{array}{l}\text { Aspergillus flavus and } \\
\text { Verticillium dahliae }\end{array}$ & $\begin{array}{c}\text { Cary et al. } \\
2000\end{array}$ \\
\hline MB39 & Synthetic & Apple & $\begin{array}{c}\text { barley } \\
\text { a-amylase }\end{array}$ & OSMp & Erwinia amylovora & Liu et al. 2001 \\
\hline MSI-99 & $\begin{array}{l}\text { Synthetic } \\
\text { analog of } \\
\text { frog } \\
\text { magainin } 2\end{array}$ & $\begin{array}{l}\text { Banana / } \\
\text { Tomato/ } \\
\text { Tobacco }\end{array}$ & $\begin{array}{l}\text { Pea vicilin / } \\
\text { expressed in } \\
\text { chloroplast }\end{array}$ & $\begin{array}{c}\text { Arabidopsis } \\
\text { ubq } 3 / \\
\text { CaMV35S/ } \\
\text { 16S rRNA } \\
\text { promoter }\end{array}$ & $\begin{array}{c}\text { Fusarium oxysporum and } \\
\text { Mycosphaerella musicola / } \\
\text { Pseudomonas syringae pv. } \\
\text { tomato but not to } \\
\text { Phytophthora infestans or } \\
\text { Alternaria solani / } \\
\text { P. syringae pv tabaci ATCC }\end{array}$ & $\begin{array}{l}\text { Chakrabarti } \\
\text { et al. } 2003 / \\
\text { Alan et al. } \\
2004 / \\
\text { DeGray et al. } \\
2001\end{array}$ \\
\hline Gallerimycin & $\begin{array}{l}\text { Greater wax } \\
\text { moth } \\
\text { Galleria } \\
\text { mellonella }\end{array}$ & Tobacco & Gallerimycin & $\begin{array}{l}\text { inducible } \\
\text { mannopine } \\
\text { synthase } \\
\text { promoter }\end{array}$ & $\begin{array}{c}\text { Erysiphe cichoracearum and } \\
\text { Sclerotinia minor }\end{array}$ & $\begin{array}{l}\text { Langen et al. } \\
2006\end{array}$ \\
\hline Heliomicin & $\begin{array}{l}\text { Heliothis } \\
\text { virescens }\end{array}$ & Tobacco & Tobacco PR1a & D35S & $\begin{array}{l}\text { Slight resistance to } \\
\text { Cercospora nicotianae }\end{array}$ & $\begin{array}{l}\text { Banzet et al. } \\
2002\end{array}$ \\
\hline Drosomycin & $\begin{array}{l}\text { Drosophila } \\
\text { melanogaster }\end{array}$ & Tobacco & Tobacco PR1a & D35S & $\begin{array}{l}\text { Slight resistance to } \\
\text { Cercospora nicotianae }\end{array}$ & $\begin{array}{l}\text { Banzet et al. } \\
2002\end{array}$ \\
\hline$\underset{\beta-d e f e n s i n}{\text { Human }} 2$ & Human & A. thaliana & $\begin{array}{l}\text { plant defensin } \\
\text {-DmAMP1 }\end{array}$ & CaMV35S & Botrytis cinerea & $\begin{array}{l}\text { Aerts et al. } \\
2007\end{array}$ \\
\hline $\begin{array}{l}\text { hCAP18 } \\
\text { LL-37 }\end{array}$ & Human & $\begin{array}{l}\text { Brassica } \\
\text { rapal } \\
\text { Tomato }\end{array}$ & $\begin{array}{l}\text { Role gene } \\
\text { encoding } \\
\text { cytokinin } \\
\text { synthesis }\end{array}$ & CaMV35S & $\begin{array}{l}\text { P. carotovorum subsp. } \\
\text { Carotovorum/ } \\
\text { Fusarium oxysporum f. sp. } \\
\text { Lycopersicil } \\
\text { Colletotrichum higginsianum/ } \\
\text { Rhizoctonia solani/ } \\
\text { X. campestris pv. vesicatoria }\end{array}$ & $\begin{array}{l}\text { Jung et al. } \\
\text { 2012/ } \\
\text { Jung } 2013\end{array}$ \\
\hline $\begin{array}{c}\text { Rabbit } \\
\text { a-defensin }\end{array}$ & Rabbit & Tobacco & not reported & CaMV35S & $\begin{array}{c}\text { Slight resistance to } \\
\text { Ralstonia solanacearum }\end{array}$ & $\mathrm{Fu}$ et al. 1998 \\
\hline
\end{tabular}

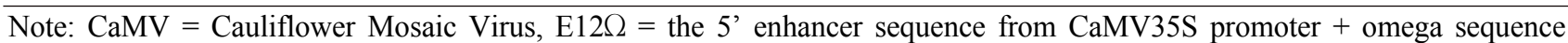
from $\mathrm{TMV}, \mathrm{E} 7 \Omega \mathrm{In}$ = synthesized high expression vector, D35S = double CaMV35S + omega sequence from TMV, FMV $=$ Figwort Mosaic Virus, PiII = promoter from proteineaseII inhibitor gene, OSMp $=$ osmotin promoter, ND $=$ Not Determined, $\mathrm{TSP}=$ total soluble protein, ${ }^{*}$ the transgenic plant displayed increased resistance to the tested organisms unless otherwise specified. 
genes have been used to control Alternaria longipes (Terras et al. 1995), V. dahliae (Gao et al. 2000), Heterobasidium annosum (Elfstrand et al. 2001), Leptosphaeria maculans (Wang et al. 1999), Phytophthora parasitica (Park et al. 2002), M. grisea (Kanzaki et al. 2002), Botrytis cinerea and Verticillium alboatrum (Turrini et al. 2004), Alternaria solani (Schaefer et al. 2005) (Table 2). The hevein Pn-AMP expressed in tobacco protects against $P$ hytophthora parasitica (Koo et al. 2002), and barley hordothionin expression in tobacco confers protection against $C$. michiganensis and Pseudomonas syringae pv. tabaci (Carmona et al. 1993). Also, human cathelicidin antimicrobial peptide carried out the substitution Met37Leu in Chinese cabbage and tomato. The expression of this peptide in cabbage and tomato plants significantly inhibited the growth of Pectobacterium carotovorum subsp. carotovorum on the plant leaves, and it conferred resistance to several fungal pathogens (Jung et al. 2012; Jung 2013a, b) (Table 2, 3, Fig. 2A, 2B).

Since pathogens have the ability to overcome gene-for- gene host defense mechanisms in the field by undergoing mutations in the cognate avirulence genes, any transgenic model based on such resistance-conferring genes may easily be evaded by pathogens. On the other hand, this problem is less likely to occur in transgenic plants overexpressing genes with more general antimicrobial activity. Antimicrobial peptides from microbial origin expressed in plants are limited.

\section{Concluding and Future Prospects}

AMPs could play strong roles in agriculture as plant protection agents. In response to a microbial attack, plants activate a complex series of responses that lead to the local and systemic induction of a broad spectrum of antimicrobial defenses (Montesinos 2007). When induced defense responses are rapidly and coordinately triggered during a given plantpathogen interaction, plants become broadly resistant to diseases. These defense responses include the strengthening
(A)

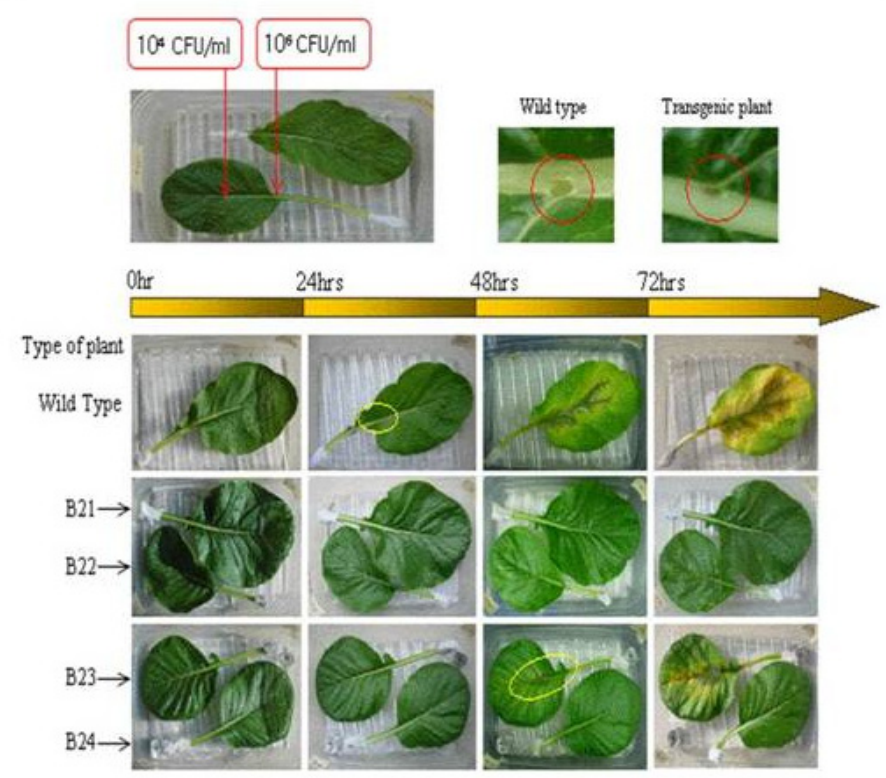

(B)

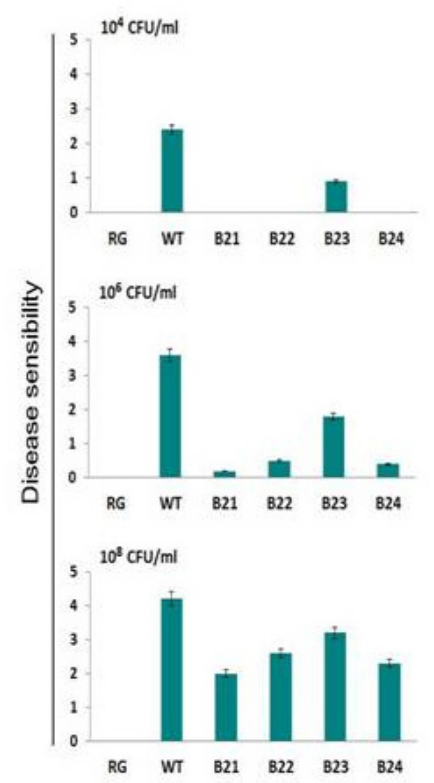

Fig. 2. (A) Temporal development of soft rot in Chinese cabbage ("Osome") plants when the leaves were inoculated with Pectobacterium carotovorum subsp. carotovorum. B21-B24 Transgenic homozygous lines. (B) Disease development in transgenic homozygous lines containing the LL-37 gene, which were inoculated with $10^{4}, 10^{6}$, or $10^{8} \mathrm{CFU} / \mathrm{mL}$ of $P$. carotovorum subsp. carotovorum. Disease manifestations were scored 3 days after inoculation. RG water, WT wild-type plant, B21-B24 LL-37 transgenic homozygous lines. Disease lesions: 0, no lesion; 1, lesion size $0.1-0.5 \mathrm{~cm} ; 2,0.5-1.5 \mathrm{~cm} ; 3,1.5-3.5 \mathrm{~cm} ; 4,3.5-5.5 \mathrm{~cm} ; 5,5.5-8.5 \mathrm{~cm}$; and 6 , over 8.5 $\mathrm{cm}$ or plant dead. (Jung et al. 2012). 
of mechanical barriers, oxidative burst, and production of antimicrobial compounds (Park 2005). Some research have been performed to bolster plant defenses against bacteria and fungi by genetically engineering plants to express antimicrobial peptides (Lee et al. 2008). Until now, studies involving the enhancement of resistance to various bacterial, fungal, and oomycete pathogens by the expression of antimicrobial peptides have been reported for rice, tobacco, poinsettia, banana, Chinese cabbage, tomato and more host species (Chakrabarti et al. 2003; Liang et al. 2002; Jung et al. 2012; Jung 2013b). Indeed these transgenic plants demonstrated reliable immunity to corresponding pathogen. However, exploitation of the great number of AMPs as active ingredients of pesticides has not been fully explored yet. Although majority of AMPs with potential uses have been studied at the in vitro level, fewer compounds have been tested on plant pathosystems, and only a few are in the market. Needless to say, more research are needed to address these areas. Further research area to explore with AMPs are its potential application for pharmaceutical purposes, and development of compounds suitable for agricultural use as pesticide ingredients. AMPs can be developed and processed commercially as less toxic and more stable compounds by improving preparative synthesis and biotechnological procedures using microbial systems or transgenic crops as plant factories.

\section{ACKNOWLEDGMENT}

This work was supported by a grant from the NextGeneration BioGreen 21 Program (No. PJ008085), Rural Development Administration, Republic of Korea.

\section{REFERENCES}

Abdallah NA, Shah D, Abbas D, Madkour M. 2010. Stable integration and expression of a plant defensin in tomato confers resistance to fusarium wilt. GM crops 1: 344-350.

Aerts AM, Thevissen K, Bresseleers SM, Sels J, Wouters P, Cammue BPA, François IEJA. 2007. Arabidopsis thaliana plants expressing human-defensin-2 are more resistant to fungal attack: functional homology between plant and human defensins. Plant Cell Reports 26: 1391-1398.

Agerberth B, JY Lee, T Bergman, M Carlquist, HG Boman, V Mutt, H Jornvall. 1991. Amino acid sequence of PR-39. Isolation from pig intestine of a new member of the family of proline-arginine-rich antibacterial peptides. Eur. J. Biochem. 202: 849-854.

Agrios GN. 2005. Plant Pathology. Academic Press, London.

Alan AR, Blowers A, Earle ED. 2004. Expression of a magainin-type antimicrobial peptide gene (MSI-99) in tomato enhances resistance to bacterial speck disease. Plant Cell Reports 22: 388-396.

Allefs S, De Jong E, Florack E, Hoogendoorn C, Stiekema W. 1996. Erwinia soft rot resistance of potato cultivars expressing antimicrobial peptide tachyplesin I. Mol.r Breed. 2: 97-105.

Arnold RR, Cole MF, McGhee JR. 1977. A bactericidal effect for human lactoferrin. Science 197: 263-265.

Bahar AA, Ren D. 2013. Antimicrobial peptides. Pharmaceuticals 6: 1543-1575.

Balls AK. 1942. A crystalline protein obtained from a lipoprotein of wheat flour. Cereal Chem. 19: 279-288.

Banzet N, Latorse MP, Bulet P, Francois E, Derpierre C, Dubald M. 2002. Expression of insect cystein-rich antifungal peptides in transgenic tobacco enhances resistance to a fungal disease. Plant Science 162: 995-1006.

Bohlmann H, Clausen S, Behnke S, Giese H, Hiller C, Reimann-Philipp U, Schrader G, Barkholt V, Apel K. 1988. Leaf-specific thionins of barley-a novel class of cell wall proteins toxic to plant-pathogenic fungi and possibly involved in the defence mechanism of plants. EMBO J. 7: 1559-1565.

Brouwer CP, Rahman M, Welling MM. 2011. Discovery and development of a synthetic peptide derived from lactoferrin for clinical use. Peptides 32: 1953-1963.

Bruix M, Jimenez MA, Santoro J, Gonzalez C, Colilla FJ, Mendez E, Rico M. 1993. Solution structure of gamma 1-H and gamma 1-P thionins from barley and wheat endosperm determined by $1 \mathrm{H}-\mathrm{NMR}$ : a structural motif common to toxic arthropod proteins. Biochemistry 32: 715-724.

Carmona MJ, Molina A, Fernández JA, López-Fando JJ, García-Olmedo F. 1993. Expression of the alpha-thionin gene from barley in tobacco confers enhanced resistance 
to bacterial pathogens. Plant J. 3: 3-457.

Cary JW, Rajasekaran K, Jaynes JM, Cleveland TE. 2000.

Transgenic expression of a gene encoding a synthetic antimicrobial peptide results in inhibition of fungal growth in vitro and in planta. Plant Science 154: 171-181.

Chakrabarti A, Ganapathi TR, Mukherjee PK, Bapat VA. 2003. MSI-99, a magainin analogue, imparts enhanced disease resistance in transgenic tobacco and banana. Planta 216: 587-596.

Choi MS, Kim YH, Park HM, Seo BY, Jung JK, Kim ST, Kim MC, Shin DB, Yun HT, Choi IS, Kim CK, Lee JY. 2009. Expression of BrD1, a plant defensin from Brassica rapa, confers resistance against brown planthopper (Nilaparvata lugens) in transgenic rices. Mol.Cells 28: 131-137.

Clark DP, S Durell, WL Maloy, M Zasloff. 1994. Ranalexin. A novel antimicrobial peptide from bullfrog (Rana catesbeiana) skin, structurally related to the bacterial antibiotic, polymyxin. J. Biol. Chem. 269: 10849-10855.

Conlon JM, Sonnevend A. 2010. Antimicrobial peptides in frog skin secretions. Methods Mol. Biol. 618: 3-14.

Conlon JM, T Halverson, J Dulka, JE Platz, FC Knoop. 1999. Peptides with antimicrobial activity of the brevinin-1 family isolated from skin secretions of the southern leopard frog, Rana sphenocephala. J. Pept. Res. 54: 522-527.

Cowland JB, Johnsen AH, Borregaard N. 1995. hCAP-18, a cathelin/ pro-bactenecin-like protein of human neutrophil specific granules. FEBS Lett. 368: 173-6.

DeGray G, Rajasekaran K, Smith F, Sanford J, Daniell H. 2001. Expression of an antimicrobial peptide via the chloroplast genome to control phytopathogenic bacteria and fungi. Plant Physiol. 127: 852-862.

Dorschner RA, Lopez-Garcia B, Massie J, Kim C, Gallo RL. 2004. Innate immune defense of the nail unit by antimicrobial peptides. J. Am. Acad. Dermatol. 50: 343-8.

Dubos RJ. 1939. Studies on a bactericidal agent extracted from a soil bacillus: II. Protective effect of the bactericidal agent against experimental Pneumococcus infections in mice. J. Exp. Med. 70: 11-17.

Dubos RJ, Hotchkiss RD. 1941. The production of bactericidal substances by aerobic sporulating bacilli. J. Exp. Med. 73: 629-640.

Elfstrand M, Fossdal C, Swedjemark G, Sitbon F, Clapham D, Olsson O, Sharma P, Lönneborg A, von
Arnold S. 2001. Identification of candidate genes for use in molecular breeding - A case study with the Norway spruce defensin-like gene, spi 1 . Silvae Genet. 50: 75-81.

Fahrner RL, T Dieckmann, SS Harwig, RI Lehrer, D Eisenberg, J Feigon. 1996. Solution structure of protegrin-1, a broad-spectrum antimicrobial peptide from porcine leukocytes. Chem. Biol. 3: 543-550.

Florack DE, Allefs S, Bollen R, Bosch D, Visser B, Stiekema WJ. 1995. Expression of giant silkmoth cecropin B genes in tobacco. Transgenic Research 4: 132-141.

Franco OL, Murad AM, Leite JR, Mendes PA, Prates MV, Bloch C Jr. 2006. Identification of a cowpea gammathionin with bactericidal activity. FEBS J. 273: 34893497.

Frank RW, Gennaro R, Schneider K, Przybylski M, Romeo D. 1990. Amino acid sequences of two prolinerich bactenectins. J. Biol. Chem. 265: 18871-18874.

Fu RZ, Peng YF, Cao GC, Chen CX, Ma JS, Zhang LM, Li WB, Sun YR. 1998. Expression of rabbit defensin NP-1 gene in transgenic tobacco plants and its activity against bacterial wilt. Chin. Sci. Bull. 43: 1519-1522.

Gao A, Hakimi SM, Mittanck CA. 2000. Fungal pathogen protection in potato by expression of a plant defensin peptide. Nat. Biotechnol. 18: 1307-1310.

Gesell J, M Zasloff, SJ Opella. 1997. Two-dimensional 1 H NMR experiments show that the 23-residue magainin antibiotic peptide is an alpha-helix in dodecylphosphocholine micelles, sodium dodecylsulfate micelles, and trifluoroethanol/ water solution. J. Biomol. NMR 9: 127-135.

Gordon YJ, Romanowski EG, McDermott AM. 2005. A review of antimicrobial peptides and their therapeutic potential as anti-infective drugs. Curr. Eye Res. 30: 505-515.

Groves ML, Peterson RF, Kiddy CA. 1965. Poliomorphism in the red protein isolated from milk of individual cows. Nature 207: 1007-1008.

Gudmundsson GH, Agerberth B, Odeberg J, Bergman T, Olsson B, Salcedo R. 1996. The human gene FALL39 and processing of the cathelin precursor to the antibacterial peptide LL-37 in granulocytes. Eur. J. Biochem. 238: 325-332.

Hancock RE. 1997. Peptide antibiotics. Lancet 349: 418422.

Hancock RE, Lehrer R. 1998. Cationic peptides: A new source of antibiotics. Trends Biotechnol. 16: 82-88. 
Hightower R, Baden C, Penzes E, Dunsmuir P. 1994. The expression of cecropin peptide in transgenic tobacco does not confer resistance to Pseudomonas syringae pv. tabaci. Plant Cell Reports 13: 295-299.

Hirsch JG. 1956. Phagocytin: A bactericidal substance from polymorphonuclear leucocytes. J. Exp. Med. 103: 589-611.

Hotchkiss RD, Dubos RJ. 1940. Fractionation of the bactericidal agent from cultures of a soil Bacillus. J. Biol. Chem. 132: 791-792.

Holak TA, A Engstrom, PJ Kraulis, G Lindeberg, H Bennich, TA Jones, AM Gronenborn, GM Clore. 1988. The solution conformation of the antibacterial peptide cecropin A: a nuclear magnetic resonance and dynamical simulated annealing study. Biochemistry 27: 7620-7629.

Huang Y, Nordeen RO, Di M, Owens LD, McBeath JH. 1997. Expression of an engineered cecropin gene cassette in transgenic tobacco plants confers disease resistance to Pseudomonas syringae pv. tabaci. Phytopathology 87: 494-499.

Hwang PM, Zhou N, Shan X. Arrowsmith CH, Vogel HJ. 1998. Three-dimensional solution structure of lactoferricin B, An antimicrobial peptide derived from bovine lactoferrin. Biochemistry 37: 4288-4298.

Kang SJ, Won HS, Choi WS, Lee BJ. 2009. De novo generation of antimicrobial LK peptides with a single tryptophan at the critical amphipathic interface. J. Pept. Sci. 15: 583-588.

Kanzaki H, Nirasawa S, Saitoh H. 2002. Overexpression of the wasabi defensin gene confers enhanced resistance to blast fungus (Magnaporthe grisea) in transgenic rice. Theor. Appl. Genet. 105: 809-814.

Kazan K, Rusu A, Marcus JP, Goulter KC, Manners JM. 2002. Enhanced quantitative resistance to Laptosphaeria maculans conferred by expression of a novel antimicrobial peptide in canola (Brassica napus L.). Mol. Breeding 10: 63-70.

Koo JC, Chun HJ, Park HC. 2002. Over-expression of a seed specific hevein-like antimicrobial peptide from Pharbitis nil enhances resistance to a fungal pathogen in transgenic tobacco plants. Plant Mol. Biol. 50: 441452.

Jha S, Chattoo BB. 2010. Expression of a plant defensin in rice confers resistance to fungal phytopathogens. Transgenic Res. 19: 373-384.

Jha S, Tank HG, Prasad BD, Chattoo BB. 2009. Expression of Dm-AMP1 in rice confers resistance to Magnaporthe oryzae and Rhizoctonia solani. Transgenic Res. 18: 59-69.

Jung YJ. 2013a. Transcriptional profiling of soft-rot resistant transgenic chinese cabbage (Brassica rapa L.) constitutively over expressing a human cathelicidin antimicrobial peptide (hCAP18/ LL-37). Plant Breed. Biotech. 1: 80-90.

Jung YJ. 2013b. Enhanced resistance to bacterial pathogen in transgenic tomato plants expressing cathelicidin antimicrobial peptide. Biotech. Bioproc. Eng. 18: 616625.

Jung YJ, Lee SY, Moon YS, Kang KK. 2012. Enhanced resistance to bacterial and fungal pathogens by overexpression of a human cathelicidin antimicrobial peptide (hCAP18/LL-37) in Chinese cabbage. Plant Biotechnol. Rep. 6: 39-46.

Langen G, Imani J, Altincicek B, Kieseritzky G, Kogel K, Vilcinskas A. 2006. Transgenic expression of gallerimycin, a novel antifungal insect defensin from the greater wax moth Galleria mellonella, confers resistance to pathogenic fungi in tobacco. Biol. Chem. 387: 549-557.

Lee SC, Hwang IS, Choi HW, Hwang BK. 2008. Involvement of the pepper antimicrobial protein CaAMP1 gene in broad spectrum disease resistance. Plant Physiol. 143: 1004-1020.

Li Z, Zhou M, Zhang Z, Ren L, Du L, Zhang B, Xu H, Xin Z. 2011. Expression of a radish defensin in transgenic wheat confers increased resistance to Fusarium graminearum and Rhizoctonia cerealis. Funct. Integr Genomics 11: 63-70.

Liang H, Catranis CM, Maynard CE, Powell WA. 2002. Enhanced resistance to the poplar fungal pathogen, Septoria musiva, in hybrid poplar clones transformed with genes encoding antimicrobial peptides. Biotechnol. Lett. 24: 383-389.

Liu Q, Ingersoll J, Owens L, Salih S, Meng R, Hammerschlag F. 2001. Response of transgenic Royal Gala apple (Malus X domestica Borkh.) shoots carrying a modified cecropin MB39 gene, to Erwinia amylovora. Plant Cell Reports 20: 306-312.

Lupetti A, Paulusma-Annema A, Welling MM, DogteromBallering H, Brouwer CP, Senesi S, Van Dissel JT, Nibbering PH. 2003. Synergistic activity of the N-terminal peptide of human lactoferrin and fluconazole against Candida species. Antimicrob. Agents Chemother. 47: 262-267. 
Lupetti A, Paulusma-Annema A, Welling MM, Senesi S, van Dissel JT, Nibbering PH. 2000. Candidacidal activities of human lactoferrin peptides derived from the $\mathrm{N}$ terminus. Antimicrob. Agents Chemother. 44: 3257-3263.

Maloy WL, Kari UP. 1995. Structure-activity studies on magainins and other host defense peptides. Biopolymers. 37: $105-122$.

Mendez E, Moreno A, Colilla F, Pelaez R, Limas GG, Mendez R, Soriano F, Salinas M, de Haro C. 1990. Primary structure and inhibition of protein synthesis in eukaryotic cell-free system of a novel thionin, gammathionin, from barley endosperm. Eur. J. Biochem. 194: 533-539.

Montesinos E. 2007. Antimicrobial peptides and plant disease control. FEMS Microbiol Lett 270: 1-11.

Nasrallah JB. 2002. Recognition and rejection of self in plant reproduction. Science 296: 305-308.

Nguyen LT, Haney EF, Vogel HJ. 2011. The expanding scope of antimicrobial peptide structures and their modes of action. Trends Biotechnol. 29: 464-472.

Nguyen LT, Schibli DJ, Vogel HJ. 2005. Structural studies and model membrane interactions of two peptides derived from bovine lactoferricin. J. Pept. Sci. 11: 379-389.

Ntui VO, Thirukkumaran G, Azadi P, Khan RS, Nakamura I, Mii M. 2010. Stable integration and expression of wasabi defensin gene in "Egusi" melon (Colocynthis citrullus L.) confers resistance to Fusarium wilt and Alternaria leaf spot. Plant Cell Reports 29: 943-954.

Ohshima M, Mitsuhara I, Okamoto M, Sawano S, Nishiyama K, Kaku H, Natori S, Ohashi Y. 1999. Enhanced resistance to bacterial diseases of transgenic tobacco plants overexpressing sarcotoxin IA, a bactericidal peptide of insect. J. Biochem. 125: 431-435.

Ohtani S, Okada T, Yoshizumi H, Kagamiyama H. 1977. Complete primary structures of two subunits of purothionin a, a lethal protein for brewer's yeast from wheat flour. J. Biochem. 82: 753-767.

Osborn RW, De Samblanx GW, Thevissen K, Goderis I, Torrekens S, Van Leuven F, Attenborough S, Rees SB, Broekaert WF. 1995. Isolation and characterisation of plant defensins from seeds of Asteraceae, Fabaceae, Hippocastanaceae and Saxifragaceae. FEBS Lett. 368: 257-262.

Oyston PC, Fox MA, Richards SJ, Clark GC. 2009. Novel peptide therapeutics for treatment of infections. J.
Med. Microbiol. 58: 977-987.

Padovan L, Scocchi M, Tossi A. 2010. Structural aspects of plant antimicrobial peptides. Curr. Protein Pept. Sci. 11: 210-219.

Pardi A, XL Zhang, ME Selsted, JJ Skalicky, PF Yip. 1992. NMR studies of defensin antimicrobial peptides.

2. Three-dimensional structures of rabbit NP-2 and human HNP-1. Biochemistry 31: 11357-11364.

Park CH, Kang YH, Chun HJ. 2002. Characterization of a stamen-specific cDNA encoding a novel plant defensin in chinese cabbage. Plant Mol. Biol. 50: 59-69.

Park JM. 2005. The hypersensitive response: a cell death during disease resistance. Plant Pathol. J. 21: 99-101.

Park SH, Kim HE, Kim CM, Yun HJ, Choi EC, Lee BJ. 2002. Role of proline, Cysteine and a disulphide bridge in the structure and activity of the anti-microbial peptide gaegurin 5. Biochem. J. 368: 171-182.

Portieles R, Ayra C, Gonzalez E, Gallo A, Rodriguez R, Chacón O, López Y, Rodriguez M, Castillo J, Pujol M, Enriquez G, Borroto C, Trujillo L, Thomma BP, Borrás-Hidalgo O. 2010. NmDef02, a novel antimicrobial gene isolated from Nicotiana megalosiphon confers high-level pathogen resistance under greenhouse and field conditions. P. Biotech. J. 8: 678-690.

Ramamoorthy A, Thennarasu S, Lee DK, Tan A, Maloy L. 2006. Solid-state NMR investigation of the membranedisrupting mechanism of antimicrobial peptides MSI-78 and MSI-594 derived from magainin 2 and melittin. Biophys. J. 91: 206-216.

Rammelkamp CH, Weinstein L. 1942. Toxic effects of tyrothricin, gramicidin and tyrocidine. J. Infect. Dis. 71: $166-173$.

Rayapuram C, Wu J, Haas C, Baldwin IT. 2008. PR-13/ Thionin but not PR-1 mediates bacterial resistance in Nicotiana attenuata in nature, and neither influences herbivore resistance. Mol. Plant Microbe. Interact. 21: 988-1000.

Reynoird JP, Mourgues F, Norelli J, Aldwinckle HS, Briset MN, Chevreau E. 1999. First evidence for improved resistance to fire blight in transgenic pear expression the attacin E gene from Hyalophora cecropia. Plant Science 149: 23-31.

Romeo D, B Skerlavaj, M Bolognesi, R Gennaro. 1988. Structure and bactericidal activity of an antibiotic dodecapeptide purified from bovine neutrophils. J. Biol. Chem. 263: 9573-9575.

Romero A, Alamillo JM, Garcia-Olmedo F. 1997. Processing 
of thionin precursors in barley leaves by a vacuolar proteinase. Eur. J. Biochem. 243: 202-208.

Sato Y, Okamoto S, Nishio T. 2004. Diversification and alteration of recognition specificity of the pollen ligand SP11/SCR in self-incompatibility of Brassica and Raphanus. Plant Cell 16: 3230-3241.

Schaefer SC, Gasic K, Cammue B, BroekaertW, van Damme EJM, Peumans WJ, Korban SS. 2005. Enhanced resistance to early blight in transgenic tomato lines expressing heterologous plant defense genes. Planta 222: $858-866$.

Scocchi M, D Romeo, M Zanetti. 1994. Molecular cloning of Bac7, a proline- and arginine-rich antimicrobial peptide from bovine neutrophils. FEBS Lett. 352: 197-200.

Seo MD, Won HS, Kim JH, Mishig-Ochir T, Lee BJ. 2012. Antimicrobial Peptides for Therapeutic Applications: A Review. Molecules 17: 12276-12286.

Selsted ME, MJ Novotny, WL Morris, YQ Tang, W Smith, JS Cullor. 1992. Indolicidin, a novel bactericidal tridecapeptide amide from neutrophils. J. Biol. Chem. 267: 4292-4295.

Sharma A, Sharma R, Imamura M, Yamakawa M, Machii H. 2000. Transgenic expression of cecropin B, an antibacterial peptide from Bombyx mori, confers enhanced resistance to bacterial leaf blight in rice. FEBS Letters 484: 7-11.

Silverstein KAT, Graham MA, Paape TD, VandenBosch KA. 2005. Genome organization of more than 300 defensin-like genes in Arabidopsis. Plant Physiol. 138: 600-610.

Sipos D, M Andersson, A Ehrenberg. 1992. The structure of the mammalian antibacterial peptide cecropin $\mathrm{P} 1$ in solution, determined by proton-NMR. Eur. J. Biochem. 209: 163-169.

Stec B, Markman O, Rao U, Heffron G, Henderson S, Vernon LP, Brumfeld V, Teeter MM. 2004. Proposal for molecular mechanism of thionins deduced from physico-chemical studies of plant toxins. J. Pept. Res. 64: 210-224.

Stotz HU, Wang Y, Spence B. 2009. A defensin from tomato with dual function in defence and development. Plant Mol. Biol. 71: 131-143.

Swathi Anuradha T, Divya K, Jami SK, Kirti PB. 2008. Transgenic tobacco and peanut plants expressing a mustard defensin show resistance to fungal pathogens. Plant Cell Reports 27: 1777-1786.

Terras FRG, Eggermont K, Kovaleva V, Raikhel NV,
Osborn RW, Kester A, Rees SB, Torrekens S, Van LF, Vanderleyden J, Cammue BPA, Broekaert WF. 1995. Small cysteine-rich antifungal proteins from radish: their role in host defense. Plant Cell 7: 573-588.

Turrini A, Sbrana C, Pitto L. 2004. The antifungal DmAMP1 protein from Dahlia merckii expressed in Solanum melongena is released in root exudates and differentially affects pathogenic fungi and mycorrhizal symbiosis. New Phytol. 163: 393-403.

Van Epps HL. 2006. Rene dubos: Unearthing antibiotics. J. Exp. Med. 203: 259.

Wang Y, Nowak G, Culley D, Hadwiger LA, Fristensky B. 1999. Constitutive expression of pea defense gene DRR206 confers resistance to blackleg (Leptosphaeria maculans) disease in transgenic canola (Brassica napus). Mol. Plant-Microbe Interact. 12: 410-418.

Yi GS, CB Park, SC Kim, C Cheong. 1996. Solution structure of an antimicrobial peptide buforin II. FEBS Lett. 398: 87-90.

Zainal Z, Marouf E, Ismail I, Fei CK. 2009. Expression of the Capsicuum annum (Chili) defensin gene in transgenic tomatoes confers enhanced resistance to fungal pathogens. Am. J. P. Physiol. 4: 70-79.

Zanetti M. 2004. Cathelicidins, multifunctional peptides of the innate immunity. J. Leukoc. Biol. 75: 39-48.

Zanetti M, Litteri L, Gennaro R, Horstmann H, Romeo D. 1990. Bactenecins, defense polypeptides of bovine neutrophils, are generated from precursor molecules stored in the large granules. J. Cell Biol. 111: 13631371.

Zasloff M. 2002. Antimicrobial peptides of multicellular organisms. Nature 415: 389-395.

Zeya HI, Spitznagel JK. 1963. Antibacterial and enzymatic basic proteins from leukocyte lysosomes: Separation and identification. Science 142: 085-1087.

Zhao X, Wu H, Lu H, Li G, Huang Q. 2013. Lamp: A database linking antimicrobial peptides. PLoS One 8: e66557.

Zhu YJ, Agbayani R, Moore PH. 2007. Ectopic expression of Dahlia merckii defensin DmAMP1 improves papaya resistance to Phytophthora palmivora by reducing pathogen vigor. Planta 226: 87-97.

Zimmermann GR, P Legault, ME Selsted, A Pardi. 1995. Solution structure of bovine neutrophil beta-defensin12: the peptide fold of the beta-defensins is identical to that of the classical defensins. Biochemistry 34 : 13663-13671. 